\title{
Weed, Disease, and Nematode Management in Onions with Biofumigants and Metam Sodium
}

\author{
Brad Geary ${ }^{1,5}$, Corey Ransom², Brad Brown ${ }^{3}$, \\ Dennis Atkinson ${ }^{4}$, and Saad $\mathrm{Hafez}^{3}$
}

ADDITIONAL INDEX WORDs. canola, mustard, onion pink root, oil seed radish, Phoma terrestris

\begin{abstract}
Summary. Onions (Allium cepa) are a high-value crop in the Treasure Valley of eastern Oregon and western Idaho. To grow quality bulbs, growers use fumigants and pesticides to control weed, pathogen, and nematode pests. Metam sodium and other commonly used pesticides are considered effective in controlling onion pests but also pose a wide range of problematic issues related to the environment, human health, and economic profitability. Biofumigant crops 'Idagold' mustard (Sinapis alba) and 'Colonel' oil seed radish (Raphanus sativus) were evaluated as substitutes for commercial fumigants in controlling soil-borne pests. During some years of this study, there was limited control of a few weed species based on visual and biomass data for metam sodium and biofumigant treatments, but the weed control was not consistent or acceptable. The severity of pink root (Phoma tervestris), a major fungal onion root pathogen, was significantly lower with metam sodium in most comparisons with other treatments. Biofumigants showed limited effects on pink root severity and are not a viable option for pink root control. Nematode damage or populations were not high enough to determine if the biofumigant and metam sodium treatments influenced their control. In some years, biofumigants reduced onion yield. The influence of these biofumigants on onion pest control was limited and their use in onion production is not warranted without significant nutrient recycling or soil quality benefits.
\end{abstract}

$\mathrm{O}$ nions grown in the Treasure Valley of Oregon and Idaho are worth about $\$ 112$ million annually (U.S. Department of Agriculture, 2002). They are grown on $\approx 20,000$ acres and account for about one-third of the annual total onion storage crop in the United States. Maximum economic returns are based on yields of bulbs greater than 3 inches in diameter and uniform in size. To ensure optimum size, quality standards, and maximize economic returns, onion growers apply fertilizers, fumigants, and other

\footnotetext{
We wish to thank the Western Sustainable Agricultural Research and Education Program and the Idaho-Eastern Oregon Onion Growers Association for financial support; Ernie Chandler, a growercooperator, for professional services; and Carol Jones, a research technician, for field support.

${ }^{1}$ Department of Plant and Wildlife Sciences, Brigham Young University, 263 WIDB, Provo, UT 84602

${ }^{2}$ Department of Plants, Soils, and Climate, Utah State University, 4820 Old Main Hill, Logan, UT 843224820

${ }^{3}$ Department of Plant, Soil, and Entomological Sciences, University of Idaho, Parma Extension and Research Center, 2963 U of I Lane, Parma, ID 83660

${ }^{4}$ Seminis Vegetable Seeds, 32537 Apple Valley Road, Parma, ID, 83660

${ }^{5}$ Corresponding author. E-mail: brad_geary@byu.edu.
}

pesticides to help plant growth and bulb development.

Treasure Valley onion fields are commonly fumigated with the commercial fumigant metam sodium to help control weeds, pathogens, and nematodes. Fumigation normally occurs the fall before spring-planted onions. Although metam sodium is considered as a possible alternative to methyl bromide (a soil fumigant implicated in ozone depletion and scheduled for phase-out of commercial agriculture), it has its own limitations. Metam sodium is considered to pose a wide range of problematic issues related to biotic entities surrounding an application site (detrimental effects on nontarget organisms, including plants, vertebrates, insects, and micro-organisms), human health (exposure to agricultural workers and general public through product volatilization and drift), and economic profitability (Amvac Chemical Corp., 2004; Saeed et al., 2000).

Mustard cultivar Idagold and oil seed radish cultivar Colonel have been suggested as biofumigant (plants that produce secondary metabolites that negatively affect plant pest populations) substitutes for commercial fumigants in controlling soil-borne pests (weeds, diseases, and nematodes) that affect the yield or quality of crops (Al-Rehiayani and Hafez, 1998; Brown and Morra, 1997). Using a general biofumigant crop before onions has considerable appeal in that it may be cheaper than commercial fumigants and may also provide other soil-quality benefits like nitrogen, phosphorus, and potassium cycling or conservation.

One of the greatest expenses for onion producers is weed control, which requires multiple herbicide applications and has led to tolerant weed species (Eberlein et al., 1992). Reducing the amount of chemicals applied to control weeds should lessen the risk of groundwater contamination, a serious concern in the Treasure Valley because of its high water tables.

Suppression of weed germination and emergence by biofumigants can reduce weed competition and has the potential to reduce fumigant and herbicide use for weed control (AlKhatib et al., 1997; Bialy et al., 1990; Boydston and Hang, 1995; Brown and Morra, 1996, 1997; Krishnan et al., 1998). Brassica green manure crops have been evaluated for weed suppression in greenhouse studies and in various crops. Krishnan et al.

\begin{tabular}{llll}
\hline $\begin{array}{l}\text { Units } \\
\begin{array}{l}\text { To convert U.S. to SI, } \\
\text { multiply by }\end{array}\end{array}$ & U.S unit & SI unit & $\begin{array}{l}\text { To convert SI to U.S., } \\
\text { multiply by }\end{array}$ \\
\hline 0.4047 & $\mathrm{acre}(\mathrm{s})$ & $\mathrm{ha}$ & 2.4711 \\
112.0851 & $\mathrm{cwt} / \mathrm{acre}$ & $\mathrm{kg} \cdot \mathrm{ha}^{-1}$ & 0.0089 \\
0.0731 & $\mathrm{fl} \mathrm{oz} / \mathrm{acre}$ & $\mathrm{L} \cdot \mathrm{ha}^{-1}$ & 13.6840 \\
0.3048 & $\mathrm{ft}$ & $\mathrm{m}$ & 3.2808 \\
9.3540 & gal $/ \mathrm{acre}$ & $\mathrm{L} \cdot \mathrm{ha}^{-1}$ & 0.1069 \\
2.54 & inch $(\mathrm{es})$ & $\mathrm{cm}$ & 0.3937 \\
1.1209 & $\mathrm{lb} / \mathrm{acre}$ & $\mathrm{kg} \cdot \mathrm{ha}^{-1}$ & 0.8922 \\
0.5425 & $\mathrm{lb} / \mathrm{yard}^{2}$ & $\mathrm{~kg} \cdot \mathrm{m}^{-2}$ & 1.8433 \\
6.8948 & $\mathrm{psi}$ & $\mathrm{kPa}$ & 0.1450 \\
0.8361 & yard & $\mathrm{m}{ }^{2}$ & 1.1960
\end{tabular}


(1998) demonstrated that three Brassica species-brown mustard (B. jun$c e a)$, rapeseed (B. napus), and white mustard (B. hirta) -inhibited germination and reduced fresh weight of kochia (Kochia scoparia), shepherd's purse (Capsella bursa-pastoris), and green foxtail (Setaria glauca) in the greenhouse; redroot pigweed (Amaranthus retroflexus) germination was reduced by rapeseed and white mustard, but not by brown mustard; and velvetleaf (Abutilon theophrasti) germination was only reduced by white mustard. The use of biofumigants in field-grown onions is intended to reduce weed populations in the Treasure Valley.

To maintain good yields with high-quality bulbs, soil fumigation is often used to control soil pathogens. One pathogen that significantly influences onion production is Phoma terrestris, the disease is commonly referred to as pink root. Although fumigation has been shown to increase yields and decrease $P$. terrestris populations (Hartz et al., 1989), there are growing concerns about the hazards to nontarget organisms from chemical fumigants (Amvac Chemical Corp., 2004; Saeed et al., 2000). Biofumigant crops, such as mustard and oil seed radish, have been proposed as alternatives to chemical fumigants in controlling soil-borne pests and minimizing hazards to nontarget organisms. Research indicates that green tissue of Brassica species can decrease the population densities of some fungal pathogens (Mayton et al., 1996).

Nematodes also pose a serious problem to onions because fields that are frequently cropped to onions have experienced significant losses due to the lesion nematode (Pratylenchus spp.). If nematode counts (based on soil sampling) are high enough to warrant inclusion of a nematicide, treatment is generally done preceding the planting of onions. A fumigation application is costly and requires careful management because of health and environmental concerns. Integration of the suitable antagonistic biofumigant crops such as mustard and oil radish would reduce the rapid build-up of nematode populations and reduce the risk of high populations that result in yield loss (Araji and Hafez, 2000).

Studies have indicated that several biofumigant crops are effective in reducing nematode populations. Rapeseed was effective in reducing the population of root knot nematodes (Meloidogyne chitwoodi) and increased the fresh weight of tomato (Solanum lycopersicum) plants (Hafez and Sundararaj, 1999). Experiments conducted in microplots and in the field confirmed that rapeseed 'Humus' and oil seed radish reduced the population of root knot nematodes and root lesion nematodes (Pratylenchus penetrans) and increased potato (Solanum tuberosum) quality and tuber yield (106\%-185\%) under Idaho conditions (Al-Rehiayani and Hafez, 1998). The substitution of plant-derived allelochemicals for synthetic organic pesticides may be an option for onion growers with nematode problems.

Some biofumigant crops have high glucosinolate concentrations that are released as pesticidal compounds (ionic thiocyanate and isothiocyanate) similar to the a.i. (methyl isothiocyanate) of the commercial fumigant metam sodium (Bialy et al., 1990). The quantities, activities, and dynamics of the release of these compounds during growth and the incorporation of biofumigant tissues can be expected to differ from those associated with commercial metam sodium applications. Therefore, the purpose of this study was to determine if the biofumigant crops 'Idagold' mustard and 'Colonel' oil seed radish preceding onions are viable options when compared with metam sodium for controlling weed, disease, and nematode pests while maintaining yield and quality of onion bulbs.

\section{Materials and methods}

The use of biofumigant crops as viable options in rotation with commercial onions was studied at two field locations on the University of Idaho's Parma Research and Extension Center. The first field location was a high-lime calcareous soil-a Nyssaton silt loam (coarse-silty, mixed, superactive, mesic Xeric Haplocalcids). The second location was a low-lime calcareous soil-a Greenleaf-Owyhee silt loam (fine-silty, mixed, superactive, mesic Xeric Calciargids). The two field locations will hereafter be termed "high lime" and "low lime" to distinguish where different components of the project took place.
Treatments at the high-lime location were arranged in a randomized complete block design, and were fallow, nontreated control; metam sodium at $30 \mathrm{gal} / \mathrm{acre}$; 'Colonel' oil seed radish seeds at $25 \mathrm{lb} / \mathrm{acre}$; and 'Idagold' mustard seeds at $25 \mathrm{lb} /$ acre. Plots were three beds wide by $40 \mathrm{ft}$ long. Onions were planted 21 Mar. 2002, 17 Mar. 2003, and 12 Mar. 2004 , and plant samples were collected on 16 Sept. 2002, 28 Aug. 2003 , and 23 Aug. 2004. Onion yield was measured at the end of the season from the three rows (minus a $2.5-\mathrm{ft}$ border on each plot end) by harvesting after the onions were lifted and field cured. Only pink root and yield data were recorded from the high-lime soil.

Treatments at the low-lime location were arranged in a split-plot design. The main plots were fallow, nontreated control; metam sodium at 30 gal/acre; 'Colonel' oil seed radish seeds at $25 \mathrm{lb} /$ acre; 'Idagold' mustard seeds at $25 \mathrm{lb} / \mathrm{acre}$; and 'Sunrise' canola (Brassica napus) seeds at 25 $\mathrm{lb} / \mathrm{acre}$. The subplots were weedy control; low herbicide inputs; high herbicide inputs; and weed-free control, hand weeded. Low herbicide inputs for two-leaf onions were bromoxynil (0.19 lb/acre a.i.; Buctril; Bayer CropScience, Research Triangle Park, NC) plus oxyfluorfen (0.094 lb/acre a.i.; Goal; Dow AgroSciences, Indianapolis) applied on 23 May 2002, 16 May 2003, and 3 May 2004. For three- to four-leaf onions, the herbicide application consisted of bromoxynil $(0.25 \mathrm{lb} /$ acre a.i. $)$ plus oxyfluorfen $(0.125 \mathrm{lb} /$ acre a.i. $)$ plus sethoxydim $(0.19 \mathrm{lb} /$ acre a.i.; Poast; BASF, Florham Park, NJ) applied on 31 May 2002, 27 May 2003, and 20 May 2004. For five- to six-leaf onions, the herbicide application consisted of oxyfluorfen $(0.25 \mathrm{lb} /$ acre a.i.) applied on 12 June 2002, 9 June 2003 , and 3 June 2004. High herbicide inputs included all of the low input applications listed above, plus a pre-emergence application of glyphosate $(0.375 \mathrm{lb} /$ acre a.i.; Roundup; Monsanto, St. Louis) and pendimethalin (1.0 lb/acre a.i.; Prowl, BASF) on 2 Apr. 2002, 7 Apr. 2003, and 26 Mar. 2004, and another application of pendimethalin $(0.5 \mathrm{lb} / \mathrm{acre}$ a.i. $)$ on 12 June 2002, 9 June 2003, and 3 June 2004.

At the high-lime and low-lime locations, onions were harvested in 
2002, 2003, and 2004. Before planting onions, rotational crops of wheat (Triticum aestivum) or barley (Hordeum vulgare) were harvested in July, and in August, the soil was tilled and seeded with the biofumigant crops at $25 \mathrm{lb} /$ acre. Nitrogen (100 lb/acre) was applied for each biofumigant crop but not to the noncropped treatments. In November, the biofumigant crops were mechanically chopped (flailed) and the green tissue was rototilled 6 inches into the soil. The chemical fumigant metam sodium was shank applied at this time at $\mathbf{3 0}$ $\mathrm{gal} / \mathrm{acre}$ to one of two plots in which biofumigants had not been planted. Two weeks after the biofumigant and metam sodium applications, the soil was disked and bedded on 22 -inch spacings for onion planting the following spring.

High- and low-lime fields were planted with 'Vaquero' yellow sweet spanish onions in March. Onions were seeded on the bed centers in a double row, 4 inches between seeds within a row, at a rate of $14 \mathrm{lb} /$ acre of pelleted seed. Both fields were lifted early in September. After 2 weeks of curing, the onions were topped and harvested.

Herbicide applications in 2002 and 2004 were made using a pressurized carbon dioxide backpack sprayer calibrated to deliver $20 \mathrm{gal} /$ acre for pre-emergence and $40 \mathrm{gal} / \mathrm{acre}$ for postemergence applications at a pressure of 30 psi. In 2003, herbicides were applied with a four-wheeler mounted sprayer calibrated to deliver $30 \mathrm{gal} / \mathrm{acre}$ of water at $30 \mathrm{psi}$ for preand postemergence applications. Plots were six beds that were 22 inches wide and $25 \mathrm{ft}$ long. Weed control was evaluated using weed counts, visual weed control ratings, and weed biomass measurements. Weed counts were taken from $10 \mathrm{ft}$ of rows 2 and 4 in each plot on 6 May, 3 June, 11 June, 25 June, and 24 July 2002; 13 May, 8 June, and 23 June 2003; and 20 Apr. and 1 June 2004. Visual weed control ratings were conducted on 29 July 2002, 11 July 2003 , and 20 July 2004. Weed biomass samples were harvested from $5 \mathrm{ft}$ of one row of each plot, separated by species, dried, and weighed on 29 July 2002, 16 July 2003, and 19 July 2004. After sampling, weeds were removed from all plots to allow for harvesting in September. Onion yield was determined by harvesting $25 \mathrm{ft}$ of the center four beds of each plot. A reduction in onion stands in the first replication of 2003 was unrelated to treatments and required the first replication to be removed from the analysis of onion yield data.

Pink root data were collected from 20 onion bulbs for each mainplot treatment; samples were collected from the weed-free control subplots to eliminate variation from weeds and herbicides. The percent area of the roots infected was visually estimated by scoring onion samples from the middle row of each plot into six classes based on the infection of the roots according to the following scale: class $1=0 \%$ infected, class $2=$ $1 \%$ to $3 \%$, class $3=4 \%$ to $6 \%$, class $4=$ $7 \%$ to $10 \%$, class $5=10 \%$ to $15 \%$, and class $6=16 \%$ to $30 \%$. Pink root samples were collected and evaluated on 31 July 2002, 5 Aug. 2003, and 26 July 2004.

Nematode populations were determined by collecting and mixing 20 soil cores $(1.9 \mathrm{~cm}$ diameter $\times 30$ $\mathrm{cm}$ deep) from the weed-free control subplots in each main plot of the lowlime soil. Samples were collected on 7 Dec. 2001, 14 May 2002, 25 Nov. 2002, 9 June 2003, 27 Nov. 2003, and 18 May 2004. Populations of root lesion nematode, stunt nematode (Tylenchorbynchus spp.), spiral nematode (Helicotylenchus variocaudatus), and ring nematode (Criconemella xenoplax) were estimated by extracting them from soil samples by Cobb's wet sieve technique (Cobb, 1918) followed by the modified centrifugal floatation technique (Jenkins, 1964).

Weed control data were analyzed using NCSS software (version 2001; NCSS Statistical Software, Kaysville, UT). When year by treatment interactions were absent, data were combined across years. Because herbicide by biofumigant interactions were not significant, weed control and biomass data are presented separately for herbicide and biofumigant main effects. Treatment means were compared using Fisher's protected least significant difference (LSD) with a critical value of $P \leq 0.05$. Because the untreated control and the hand-weeded plots were not included in the analysis of herbicide programs for visual weed control, significant differences between the low- and high-input herbicide treatments were determined using a paired $t$ test. Pink root, nematode, and high-lime yield data were analyzed by analysis of variance using the GLM procedure of SAS (version 8.2; SAS Institute, Cary, NC). Treatment means were compared using Fisher's protected LSD with a critical value of $P \leq 0.05$. Pink root data were transformed using square root transformation $(\sqrt{\text { pink root data }+0.5})$.

\section{Results}

There were few effects of biofumigant treatments on weed counts, visual weed control (data not shown), or weed biomass (Table 1). Weed counts were collected throughout the growing season with no significant differences among treatments (data not shown). Visual weed control estimates indicate that fallapplied metam sodium provided partial control of some species [redroot pigweed (Amaranthus retroflexus), common lambsquarters (Chenopodium berlandieri), barnyard grass (Echinochloa crus-galli), and green foxtail (Setaria glauca)] in 2002 only. Also in 2002, redroot pigweed control was significantly better with the oil seed radish than the fallow treatment, and lambsquarters control was significantly better with the mustard than with the fallow treatment (data not shown).

Weed biomass data were combined across all 3 years for redroot pigweed and common lambsquarters. Hairy nightshade (Solanum sarrachoides), kochia, and total weed biomass were combined across 2002 and 2004. Barnyard grass and green foxtail biomass could not be combined across years. Main effects were not significantly different for all 3 years across all fumigant and biofumigant treatments (Table 1). Weed biomass was significantly reduced by the highinput herbicide treatment in all years when compared with the untreated control (Table 1). In most cases, the low-input herbicide treatment also reduced weed biomass when compared with the untreated control. The exceptions were in 2003 where kochia, barnyard grass, green foxtail, and total weed biomass in the lowinput herbicide plots was equal to those in the untreated plots (Table 1).

Onion yield in the low-lime soil was unaffected by biofumigant crops 
Table 1. Influence of fumigant (metam sodium) and weed control program main effects on dry weight weed biomass.

Fumigant main effects are averaged over no-input, low-input, and high herbicide-input treatments for commercial onions. Weed control through herbicides main effects are averaged overall fumigant treatments.

\begin{tabular}{|c|c|c|c|c|c|c|c|c|c|c|c|}
\hline \multirow[b]{3}{*}{ Main effects } & \multicolumn{11}{|c|}{ Weed biomass } \\
\hline & \multirow{2}{*}{$\begin{array}{l}\text { Redroot } \\
\text { pigweed } \\
2002-04 \\
\end{array}$} & \multirow{2}{*}{$\begin{array}{c}\text { Common } \\
\text { lambsquarters } \\
2002-04 \\
\end{array}$} & \multicolumn{2}{|c|}{$\begin{array}{c}\text { Hairy } \\
\text { nightshade }\end{array}$} & \multicolumn{2}{|c|}{ Kochia } & \multicolumn{3}{|c|}{ Annual grass ${ }^{\mathrm{z}}$} & \multicolumn{2}{|c|}{ Total } \\
\hline & & & 2003 & $\begin{array}{c}2002+ \\
2004\end{array}$ & 2003 & $\begin{array}{c}2002+ \\
2004\end{array}$ & 2002 & 2003 & 2004 & 2003 & $\begin{array}{c}2002+ \\
2004\end{array}$ \\
\hline & & & & & $(\mathrm{lb} / \mathrm{s}$ & )$^{y}$ & & & & & \\
\hline \multicolumn{12}{|c|}{ Biofumigant/fumigant } \\
\hline Mustard & 0.13 & 0.13 & 0.22 & 0.04 & 1.30 & 0.23 & 0.07 & 0.41 & 0.42 & 2.26 & 0.77 \\
\hline Canola & 0.15 & 0.04 & 0.11 & 0.04 & 0.80 & 0.33 & 0.06 & 0.12 & 0.26 & 1.44 & 0.72 \\
\hline Oil seed radish & 0.09 & 0.13 & 0.13 & 0.09 & 1.50 & 0.22 & 0.12 & 0.51 & 0.42 & 2.37 & 0.73 \\
\hline $\operatorname{LSD}(0.05)^{\mathrm{x}}$ & NS & NS & NS & NS & NS & NS & NS & NS & NS & NS & NS \\
\hline \multicolumn{12}{|l|}{ Weed control } \\
\hline Weedy control & 0.34 & 0.21 & 0.52 & 0.17 & 1.55 & 0.70 & 0.25 & 0.26 & 0.76 & 3.07 & 1.90 \\
\hline
\end{tabular}

${ }^{\mathrm{z} A n n u a l ~ g r a s s ~ w a s ~ a ~ m i x t u r e ~ o f ~ b a r n y a r d ~ g r a s s ~ a n d ~ g r e e n ~ f o x t a i l . ~}$

$\mathrm{llb} / \mathrm{yard}^{2}=0.5425 \mathrm{~kg} \cdot \mathrm{m}^{-2}$.

LSD $(0.05)=$ least significant difference at $P \leq 0.05$

${ }^{\text {ss Nonsignificant. }}$

in 2002 and 2003. In 2004, yield was significantly less after mustard and canola when compared with fallow and metam sodium treatments, and yield was significantly less following radish when compared with the fallow (Table 2). In the high-lime soil, onion yield was affected by biofumigants only in 2003 when yields were lower with the radish treatment than with the fallow treatment. Onion yields from metam sodium-treated plots were significantly higher than in the fallow in 2003 and were significantly higher in the radish and mustard treatments in 2004.

Herbicide-treated (low- and high-input weed control) and weedfree (hand-weeded) plots yielded greater than untreated plots all 3 years. In 2002, the high-input and weed-free treatments had significantly higher yields than the lowinput treatment. In 2003, onion yields were similar between both herbicide treatments and the handweeded control. In 2004 , the weedfree treatment was significantly better than the low- and high-input treatments (Table 2).

In 2002, 'Colonel' oil seed radish and 'Sunrise' canola volunteered, averaging 1.0 and 0.25 plants $/$ yard $^{2}$, respectively. In 2003, oil seed radish volunteered, producing a significant number of plants ( 35 plants/yard ${ }^{2}$ ). Canola also volunteered, but not in

Table 2. Onion yield as influenced by main effects of fumigant and weed control in the low- and high-lime soil in 2003 and 2004.

\begin{tabular}{|c|c|c|c|c|c|c|}
\hline \multirow[b]{2}{*}{ Main effects } & \multicolumn{3}{|c|}{ Onion yield low-lime } & \multicolumn{3}{|c|}{ Onion yield high-lime } \\
\hline & 2002 & 2003 & 2004 & 2002 & 2003 & 2004 \\
\hline & \multicolumn{3}{|c|}{$-\cdots$} & \multicolumn{3}{|c|}{ cwt/acre ${ }^{\mathrm{z}} \ldots$} \\
\hline \multicolumn{7}{|c|}{ Biofumigant/fumigant } \\
\hline Fallow & 614 & 386 & 717 & 587 & 407 & 705 \\
\hline Metam sodium & 630 & 392 & 653 & 601 & 392 & 841 \\
\hline Mustard & 529 & 324 & 570 & 565 & 357 & 713 \\
\hline Canola & 539 & 336 & 568 & - & - & - \\
\hline Oil seed radish & 552 & 352 & 635 & 555 & 340 & 668 \\
\hline $\operatorname{LSD}(0.05)^{\mathrm{y}}$ & NS & NS & 80 & NS & 62 & 109 \\
\hline \multicolumn{7}{|l|}{ Weed control } \\
\hline Weedy control & 57 & 74 & 0 & - & - & - \\
\hline Low input & 447 & 426 & 788 & - & - & - \\
\hline High input & 573 & 439 & 797 & - & - & - \\
\hline Weed free & 619 & 494 & 930 & - & - & - \\
\hline LSD $(0.05)$ & 72 & 76 & 77 & - & 一 & - \\
\hline
\end{tabular}

${ }^{\mathrm{z}} \mathrm{l} \mathrm{cwt} / \mathrm{acre}=112.085 \mathrm{~kg} \cdot \mathrm{ha}^{-1}$.

${ }^{y_{L S D}}(0.05)=$ least significant difference at $P \leq 0.05$.

Ns Nonsignificant.

significant numbers. In 2004, oil seed radish again volunteered. 'Idagold' mustard did not volunteer in any year.

Pink root severity in the low-lime soil was significantly $(P \leq 0.05)$ lower in metam sodium-treated plots than all other treatments in 2002 (Table $3)$. There were no significant differences among the treatments in 2003 , but in 2004, metam sodium and mustard treatments had significantly lower $(P \leq 0.05)$ pink root severity when compared with radish and canola. Fallow plots were not signifi- cantly different from any other treatment in 2004. In the high-lime soil, metam sodium had significantly lower $(P \leq 0.05)$ pink root severity than all other treatments in 2002 and 2004. In 2003, metam sodium had significantly less pink root than the oil seed radish biofumigant, but was not significantly different from the mustard or fallow treatments (Table 3).

Root lesion, stunt, spiral, and ring nematodes were recovered from soil samples. Mean counts per treatment for 2002 and 2003 are given in 
Table 4 , but there were no significant differences $(P \leq 0.05)$ in nematode populations among the treatments at any sampling period. Bulb and root samples were not evaluated for nematode damage because there were no apparent nematode symptoms in the onions during all 3 years of this study.

\section{Discussion}

Fewer weeds were expected through the suppression of weed germination and emergence by biofumigants as noted by $\mathrm{Al}-\mathrm{Khatib}$ et al. (1997), Bialy et al. (1990), Boydston and Hang (1995), Brown and Morra (1996, 1997), and Krishnan et al. (1998). However, our study had only limited control of a few weed species based on weed counts, visual estimates, and biomass data. Control was not consistent nor did it show any trends over 3 years. It is possible that the biofumigants and metam sodium did reduce weed germination and emergence because they had an effect on the stand of onions (Geary et al., 2006). However, the number of seeds in the soil was unknown and may have been large, thus prohibiting detection of differences in germination and emergence through weed counts, visual estimates, and biomass data.

The high-input herbicide program frequently used by onion growers in the Treasure Valley increased control of all weed species in all 3 years except for barnyard and green foxtail grass in 2003. The low-input program also increased control when compared with the untreated control in 8 of the 11 weed biomass columns (Table 1). Herbicide control of weeds was good, and it is understandable why growers are hesitant to use other options such as biofumigants until these alternatives are proven to provide a benefit for controlling weeds. Onion yields with herbicide inputs were at least six times higher than the weedy control and close to, or as good as, the hand-weeded, weed-free plots.

Yield was reduced by volunteers from oil seed radish and canola due to early competition with the onions. Each year, volunteer biofumigants were removed by hand, but without the use of hand labor, biofumigants would not have been effectively controlled by herbicide applications and would have been as competitive with

Table 3. Pink root severity on 'Vaquero' onion roots when treated with biofumigants and the fumigant metam sodium in low- and high-lime soils.

\begin{tabular}{lccc}
\hline Treatment & 2002 & 2003 & 2004 \\
\hline & & & \\
Low-lime soils & $2.9 \mathrm{a}$ & $1.25 \mathrm{a}$ & $2.4 \mathrm{~b}$ \\
Mustard & $2.7 \mathrm{a}$ & $1.58 \mathrm{a}$ & $3.4 \mathrm{a}$ \\
Oil seed radish & $2.5 \mathrm{a}$ & $1.48 \mathrm{a}$ & $2.8 \mathrm{a} \mathrm{b}$ \\
Fallow & $2.4 \mathrm{a}$ & $1.85 \mathrm{a}$ & $3.3 \mathrm{a}$ \\
Canola & $1.5 \mathrm{~b}$ & $1.45 \mathrm{a}$ & $2.3 \mathrm{~b}$ \\
Metam sodium & 0.8 & 0.96 & 0.87 \\
LSD $(0.05)^{\mathrm{y}}$ & & & \\
High-lime soils & $1.89 \mathrm{a}$ & $1.13 \mathrm{a}$ & $1.80 \mathrm{a}$ \\
Mustard & $2.03 \mathrm{a}$ & $1.29 \mathrm{a}$ & $1.75 \mathrm{a}$ \\
Oil seed radish & $2.03 \mathrm{a}$ & $1.12 \mathrm{a}$ & $1.99 \mathrm{a}$ \\
Fallow & $1.23 \mathrm{~b}$ & $0.53 \mathrm{~b}$ & $0.35 \mathrm{~b}$ \\
Metam sodium & 0.436 & 0.34 & 0.41 \\
LSD $(0.05)^{\mathrm{y}}$ & & & \\
\hline
\end{tabular}

${ }^{2}$ Pink root data were collected from 20 onion bulbs and infection was visually estimated on the scale: class $1=0 \%$, class $2=1 \%$ to $3 \%$, class $3=4 \%$ to $6 \%$, class $4=7 \%$ to $10 \%$, class $5=10 \%$ to $15 \%$, class $6=16 \%$ to $30 \%$.

${ }^{y_{\text {LSD }}}(0.05)=$ least significant difference at $P \leq 0.05$.

Table 4. Mean counts of root lesion nematode, stunt nematode, spiral nematode, and ring nematode when treated with biofumigants and the fumigant metam sodium in low-lime soils in 2002 and 2003.

\begin{tabular}{|c|c|c|c|c|c|c|c|c|}
\hline \multirow[b]{2}{*}{ Treatment $^{\mathrm{z}}$} & \multicolumn{4}{|c|}{2002} & \multicolumn{4}{|c|}{2003} \\
\hline & $\begin{array}{l}\text { Root } \\
\text { lesion }\end{array}$ & Stunt & Spiral & Ring & $\begin{array}{l}\text { Root } \\
\text { lesion }\end{array}$ & Stunt & Spiral & Ring \\
\hline & - & & Nemato & es (no. & $500 \mathrm{~cm}^{3}$ & of soil $)^{y}$ & & \\
\hline Fallow & 517 & 137 & 0 & 3 & 318 & 28 & 0 & 0 \\
\hline Metam sodium & 1,260 & 407 & 80 & 0 & 145 & 43 & 0 & 0 \\
\hline Mustard & 1,145 & 575 & 0 & 0 & 148 & 75 & 0 & 0 \\
\hline Canola & 1,227 & 617 & 0 & 0 & 175 & 25 & 0 & 0 \\
\hline Oil seed radish & 927 & 320 & 5 & 0 & 243 & 50 & 0 & 0 \\
\hline
\end{tabular}

zThere were no significant differences among the treatments at $P \leq 0.05$ in either year.

${ }^{y}$ Nematode counts are the mean number of nematodes sampled from the weed-free control subplots in each main plot; 1 nematode $/ 500 \mathrm{~cm}^{3}=56.6337$ nematodes $/ \mathrm{ft}^{3}$.

the onion crop as many other weeds. Although the mustard did not volunteer in any year, onion yield was reduced by the mustard in 2002 and 2004. The results suggest that biofumigants are affecting seedbed conditions in a way that is reducing yield. Reductions in onion stand almost always resulted in reduced yields. Reduced yields occurred from biofumigant plants competing for resources as volunteers and by reducing stand numbers through inhibition of seed germination and emergence, either from residual isothiocyanate activity, poorer seed soil contact, or other means due to incorporation of organic residues. Herbicide treatments did not affect onion stand in any year (Geary et al., 2006).

Overall, the use of biofumigant crops provided inadequate weed control in all 3 years and reduced onion yield in 1 of 3 years. Additionally, oil seed radish and canola volunteered at varying levels in all 3 years and were difficult to control with herbicides and required removal by hand. Onion growers cannot accept the negative effects caused by the biofumigant crops without some significant increase in positive weed suppression.

Pink root severity on onion roots was significantly lower in metam sodium treatments than all other treatments in five of six samplings (Table 3), consistent with a previous report (Hartz et al., 1989). Pink root severity after biofumigant crops did not differ significantly from the fallow treatment, except in 2004 when oil seed radish and canola appeared to exacerbate pink root in the low-lime 
soil. There was no evidence for pink root control with the biofumigant crops in this study.

Glucosinolates from the biofumigant crops, which break down to ionic thiocyanate and isothiocyanate, averaged $0.0018 \mathrm{fl} \mathrm{oz/acre}$ and $0.0028 \mathrm{fl} \mathrm{oz} /$ acre for radish and mustard, respectively, in the highlime soil (Brown et al., 2006). Although metam sodium breaks down to methyl isothiocyanate, when applied at $30 \mathrm{gal} / \mathrm{acre}$ it becomes $\approx 1328 \mathrm{fl} \mathrm{oz} /$ acre, depending on conversion efficiency from metam sodium to methyl isothiocyanate (Draper and Wakeham, 1993; Geddes et al., 1995). The difference in the amount of a.i. applied per acre of biofumigant plants and metam sodium is large and is likely the contributing factor for metam sodium reducing the amount of pink root in comparison with the biofumigant crops.

The canola biofumigant treatment was included in the low-lime soil study as a treatment involving incorporated biomass containing little if any glucosinolates. The intention was to isolate the effects of tissuederived glucosinolates from vegetative biomass effects with little glucosinolate. Although canola and oil seed radish never differed in pink root severity, their pink root severities were greater than mustard or fallow (no biomass and no glucosinolates) in one comparison. Mustard and fallow treatments never differed in pink root severity in all 3 years. Thus, we were unable to distinguish between biomass effects due to plant glucosinolates or other biomass-induced conditions.

In summary, from a pest control perspective, oil seed radish, mustard, and canola biofumigants provided little advantage in commercial onion production. They also reduced onion yield in some instances. Therefore, their use is not recommended for Treasure Valley onion production.

\section{Literature cited}

Al-Khatib, K., C. Libbey, and R. Boydston. 1997. Weed suppression with Brassica green manure crops in green pea. Weed Sci. 45:439-445.

Al-Rehiayani, S. and S. Hafez. 1998. Host status and green manure effect of selected crops on Meloidogyne chitwoodi race 2 and Pratylenchus neglectus. Nematropica 28(2):213-230.

Amvac Chemical Corp. 2004. Vapam HL label for product use, EPA registration \#5481-468. 28 Apr. 2008. <http://www. cdms.net/LabelsMsds/LMDefault.aspx? $\mathrm{pd}=3174>$.

Araji, A.A. and S.L. Hafez. 2000. The economic and environmental impact of nematode research and extension program on the Idaho agricultural industry. Univ. Idaho College Agr. Ext. Bul. 818.

Bialy, Z., W. Oleszek, J. Lewis, and G.R. Fenwick. 1990. Allelopathic potential of glucosinolates (mustard oil glycosides) and their degradation products against wheat. Plant Soil 129:277-281.

Boydston, R.A. and A. Hang. 1995. Rapeseed (Brassica napus) green manure crop suppresses weeds in potato (Solanum tuberosum). Weed Technol. 9:669-675.

Brown, B., B. Geary, M. Morra, and R. Borek. 2006. Biofumigant response to phosphorus. Second Intl. Biofumigation Symp., Moscow, ID, 25-29 June 2006. (Abstr.)

Brown, P.D. and M.J. Morra. 1996. Hydrolysis products of glucosinolates in Brassica napus tissues as inhibitors of seed germination. Plant Soil 181(2): 307-316.

Brown, P.D. and M.J. Morra. 1997. Control of soil-borne plant pests using glucosinolate-containing plants. Adv. Agron. 61:167-231.

Cobb, N.A. 1918. Estimating the nematode population of soil. U.S. Dept. Agr., Agr. Tech. Circ. 1.
Draper, W.M. and D.E. Wakeham. 1993. Rate constants for metam-sodium cleavage and photodecomposition in water. J. Agr. Food Chem. 41:1129-1133.

Eberlein, C.V., K. Al-Khativb, M.J. Guttieri, and E.P. Fuerst. 1992. Distribution and characteristics of triazine resistant Powell amaranth (Amaranthus powellii) in Idaho. Weed Sci. 40:507-512.

Geary, B., B. Brown, C. Ransom, and S. Hafez. 2006. Biofumigants in commercial onion production to control weed, nematode and disease pests. Second Intl. Biofumigation Symp., Moscow, ID, 25-29 June 2006. (Abstr.)

Geddes, J.D., G.C. Miller, and G.E. Taylor. 1995. Gas phase photolysis of methyl isothiocyanate. Environ. Sci. Technol. 29:2590-2594.

Hafez, S.L. and P. Sundararaj. 1999. Efficacy of seed crop meals for the management of Columbia root-knot nematode Meloidogyne chitwoodi on tomato under greenhouse conditions. Nematropica 29:171-177.

Hartz, T.K., C.R. Bogle, D.A. Bender, and F.A. Avila. 1989. Control of pink root disease in onion using solarization and fumigation. J. Amer. Soc. Hort. Sci. 114:587-589.

Jenkins, W.R. 1964. A rapid centrifugal flotation technique for separating nematodes from soil. Plant Dis. Rptr. 48:692.

Krishnan, G., D.L. Holshouser, and S.J. Nissen. 1998. Weed control in soybean (Glycine $\max$ ) with green manure crops. Weed Technol. 12:97-102.

Mayton, H.S., C. Olivier, S.F. Vaughn, and R. Loria. 1996. Correlation of fungicidal activity of Brassica species with allyl isothiocyanate production in macerated leaf tissue. Phytopathology 86:267-271.

Saeed, I.A., D.I. Rouse, and J.M. Harkin. 2000. Methyl isothiocyanate volatilization from fields treated with metamsodium. Pest Mgt. Sci. 56:813-817.

U.S. Department of Agriculture. 2002. Idaho and Oregon data: Vegetables. 12 May 2002. <http://www.nass.usda.gov/ Census/Create_Census_US_CNTY.jsp>. 